\title{
Development of Higher Education E-Learning Using E-Learning Maturity Model (eMM)
}

\author{
Roni Herdianto \\ School of Electrical Engineering and \\ Informatics \\ Institut Teknologi Bandung \\ Bandung, Indonesia \\ 40132
}

roni.m38@gmail.com

\author{
Yoanes Bandung \\ School of Electrical Engineering and \\ Informatics \\ Institut Teknologi Bandung \\ Bandung, Indonesia \\ 40132
}

ybandung@gmail.com

\begin{abstract}
Achievement of competency is strongly influenced by learning strategies. Learning strategies have evolved quite rapidly in line with the development of Information and Communication Technology (ICT). One of them is e-learning. E-learning has become a necessity for academic society to support and provide a means of learning. The method used is e-Learning Maturity Model (eMM). This model is based on the Capability Maturity Model (CMM) and Software Process Improvement and Capability Determination (SPICE). eMM process has five categories: Learning, Development, Support, Evaluation, and Organization. Each process has a five-dimensional process, including: delivery, planning, definition, management, and optimization. eMM goal is to help institutions to assess and compare the potential ability to develop, deploy, and support existing e-learning. Assessment results provide comprehensive information to be used as a guide to design strategic and operational planning and investment, or designing a roadmap to higher education institutions in improving the process of e-learning. Expected by using eMM, development and utilization of e-learning can be a maximum according to the needs of students, staff, and institutions.
\end{abstract}

\section{Keywords}

ICT, E-learning, eMM, strategic and operational planning, roadmap.

\section{INTRODUCTION}

With the development of information technology as quickly as is happening today, almost no field that is not touched, no exception in world of higher education. IT is not only useful for the things that indeed directly exploit the potential of the technology, but also encourage the emergence of new ways of doing work/activities. The duty of universities is to take advantage IT development as well as possible for the purpose of the higher education service quality and affordable by the parties-those who need it.

The degree of utilization of IT in their respective colleges is different of course. Many factors determine how far the college can explore technology to its interests, but the important thing is how, with the capabilities, colleges do optimizing the utilization of IT. All colleges can take advantage of IT for e-learning for example, but utilization rate of IT for e-learning at universities in Indonesia will obviously differ from those in Japan universities.
In the event Comdex in 2001, John Chambers, CEO Cisco said that e-learning is "the next killer application". He pointed to a fundamental change of paradigm and process learning and its implications. The great potential of e-learning is predicted since 7 years ago, but many are not yet understand the essence of elearning and how to utilize IT in it.

The change of learning paradigm strategies from teacher-centered to learner-centered encourage academicians to use e-learning as a learning method. Utilization of e-learning is expected to motivate quality improvement learning and teaching materials, quality activities and student independence, and communication between lecturers and students and between students. E-learning can also be used to overcome limitations of the classroom as well as the barriers of distance and time, in the implementation of learning activities of teaching.

\section{E-LEARNING}

\subsection{Definition}

Many definitions of e-learning, but in the context of a discussion utilization of IT to support learning, more generic definition easily accommodate different points of view so it is more suitable is used. This focus on full on-line course delivery is also part of the following definitions: e-learning is "computer-based training delivered over intranets and the internet [1], e-learning is "the delivery of a learning, training or education program by electronic means, e-learning involves the use of a computer or electronic device (e.g. a mobile phone) to provide training, educational or learning material" [2], e-learning is "a term covering a wide set of applications and processes, such as web-based learning, computer-based learning, virtual classrooms, and digital collaboration. It includes the delivery of content via internet, intranet/extranet (LAN/WAN), audio and videotape, satellite broadcast, interactive TV, CD-ROM, and more" [3], or e-learning is "distance education or education delivered on the web" [4].

One writer defines e-learning as "pedagogy empowered by digital technology" [5]. In the UNESCO publication, Teacher Development in an E-learning Age: A Policy and Planning Guide, the approach here is to start with the observation that elearning is learning by communicating using the internet and interacting with content accessed on the internet, all within the context of sound pedagogy. Of some understanding of e-learning as mentioned above can be concluded that e-learning is the delivery of a learning (pedagogy aspect), training or education program using the internet and interacting with content accessed 
on the internet such as web-based learning, computer-based learning, virtual classrooms, and digital collaboration for distance education.

\subsection{Category}

This approach shows e-learning to have two dimensions: (1). communication-communicating using the internet or web; and (2). content-content on the web. The two dimensions of elearning, communication and content, are described separately, above, as a matter of convenience. We now put them together to build a two-dimensional model of e-learning. In a way that is not possible when working with a single dimension, we can now position different categories of e-learning within the two axes as each varies along both communication and content dimensions. Figure 1 is the end result.

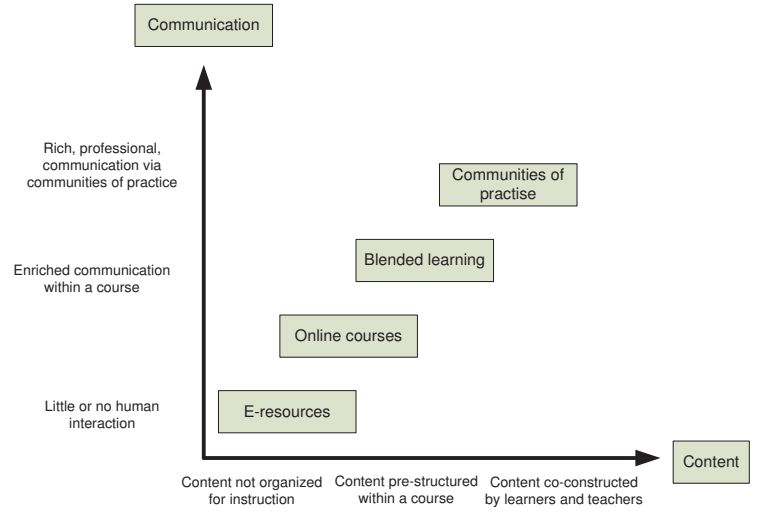

Figure 1. Four basic categories of e-learning [6].

Four basic categories of e-learning [6]: (1) E-resources refer here to information and learning resources on the web that are available for access by teachers and learners for instruction; (2) Online courses are offered by many teaching institutions around the world, usually for a fee, and often as part of a diploma or degree; (3) Blended learning is a term to describe learning that combines different learning environments: typically the use of learning via the web and face-to-face teaching; and (4) Communities of practice are groups of people such as teachers or even students who share a common interest.

\subsection{Component}

Some e-learning components are: (1) Devices. Hardware can be a PC, webcam, servers, speakers, printers, scanners, and others. The software in question is related to the software application software for documentation, administration, tracking, reporting, training programs, classes and activities online, e-learning programs, and training content (Moodle, ATutor); (2) Network infrastructure. Basically, the development and advancement of e-learning is inseparable from the reliability of network infrastructure that supports it. A major challenge in network design is the speed of data transmission and connectivity; (3) The materials/content. This component is presented basic learning materials that can be accessed by learners/students who form the main learning materials or additional instructional material. The presentation material can be fully or only the subjects presented; (4) Strategy interaction. There are several types of strategies that can be done for interaction between teachers/lecturers and learners/students, among other practices and exercises, tutorials, games, simulations, and others; and (5) Users. Users here can originate from within institutions such as teacher/lecturer, learner/student, employee, and from outside institutions such as public education or both from the outside of education.

\section{3. eMM}

\subsection{Introduction to eMM}

E-Learning Maturity Model (eMM) is a model that is based on the idea of the Capability Maturity Model (CMM, Paulk, et al., 1993) and SPICE (Software Process Improvement and Capability Determination, El Emam et al., 1998; SPICE 2002 ). E-Learning Maturity Model (eMM) is created and developed by S Marshall from the University of Victoria, New Zaeland and G Mitchell from Queensland University of Technology, Australia [7].

The key to the CMM model is that it is designed to provide good engineering and organisational management practices [8]. It achieves this through a structure that breaks each level into a number of process areas. Each of these process areas is in turn organized into a number of sections called common features, which are used to organise the key practices that accomplish the goals of the relative process areas. The model can more correctly be seen as a hierarchy as shown in Figure 2 below.

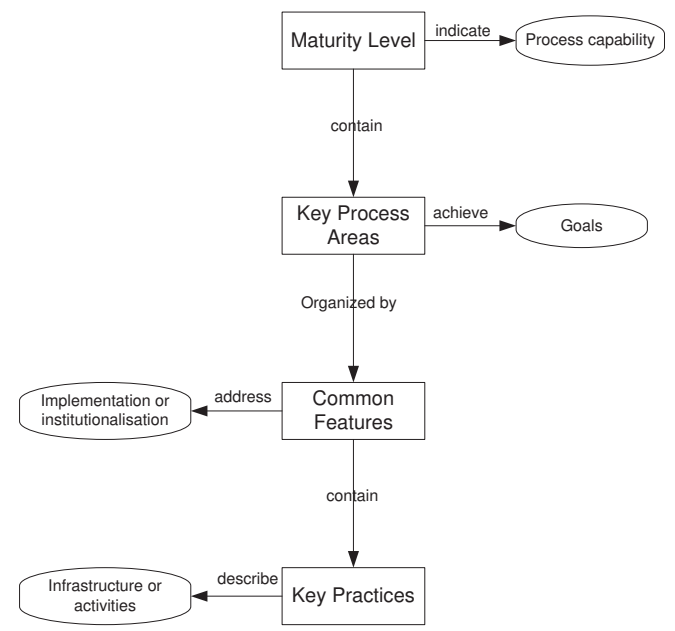

Figure 2. Hirearchial Structure of The Capability Maturity Model [9].

The key to the SPICE methodology extends the flexibility of the CMM by providing a framework for systematically improving processes while acknowledging that improvement in complex systems occurs gradually and simultaneously in different levels [8]. Under the SPICE model, practices that result in improved process capability are explicitly identified for a number of categories that impact on the organizational process capability. Description of Process Categories for an e-Learning Capability Measure are: (1) Learning Processes that directly impact on pedagogical aspects of e-Learning; (2) Development Processes surrounding the creation and maintenance of e-Learning resources; (3) Co-ordination Processes surrounding the oversight and management of e-Learning; (4) Evaluation Processes surrounding the evaluation and quality control of e-Learning through its entire lifecycle; and (5) Organisation Processes associated with institutional planning and management. 


\subsection{Key eMM Concepts}

Key eMM Concepts is Capability [7]. Capability, in the context of this model, refers to the ability of an institution to ensure that elearning design, development and deployment is meeting the needs of the students, staff and institution. As well, capability includes the ability of an institution to sustain e-learning support of teaching as demand grows and staff change. The assessment of capability in a complex area such as e-learning is difficult and necessarily involves reducing large amounts of detail into a broader overview that supports management decision making and strategic planning. This model presents, a number of opportunities [8]: (1) an e-learning model could provide a road map for higher education institutions looking to improve their e-learning processes; (2) An accepted framework might also provide academics with the necessary means to encourage greater institutional involvement and provide University management with the framework necessary to frame long term institutional planning; (3) Support for institutional planning might be enhanced by the ability of an institution or even a school to benchmark its current capability in an effort to identify and prioritize necessary improvements in its current practices; and (4) a view to identifying the key practices, heuristics or activities necessary for achieving improvements in e-learning activities.

\subsection{Processes}

The key difference from the original SPICE model is the introduction of the Learning area, which replaces the Customer/Supplier area used in software engineering. Processes define an aspect of the overall ability of institutions to perform well in the given process area, and thus in e-learning overall.

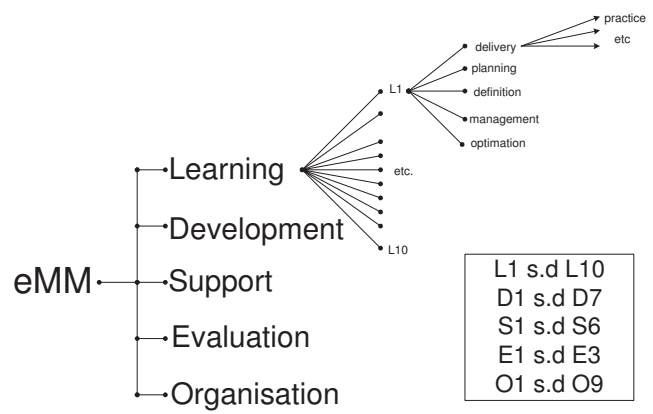

Figure 3. Schematic of eMM [7].

Table 1. eMM processes and process area [7]

Learning : Processes that directly impact on pedagogical aspects of e-learning

\begin{tabular}{|l|l|}
\hline L1. & $\begin{array}{l}\text { Learning objectives guide the design and implementation } \\
\text { of courses }\end{array}$ \\
\hline L2. & $\begin{array}{l}\text { Students are provided with mechanisms for interaction } \\
\text { with teaching staff and other students }\end{array}$ \\
\hline L3. & Students are provided with e-learning skill development \\
\hline L4. & $\begin{array}{l}\text { Students are provided with expected staff response times } \\
\text { to student communications }\end{array}$ \\
\hline L5. & $\begin{array}{l}\text { Students receive feedback on their performance within } \\
\text { courses }\end{array}$ \\
\hline L6. & $\begin{array}{l}\text { Students are provided with support in developing research } \\
\text { and information literacy skills }\end{array}$ \\
\hline
\end{tabular}

\begin{tabular}{|c|c|}
\hline L7. & Learning designs and activities actively engage students \\
\hline L8. & $\begin{array}{l}\text { Assessment is designed to progressively build student } \\
\text { competence }\end{array}$ \\
\hline L9. & $\begin{array}{l}\text { Student work is subject to specified timetables and } \\
\text { deadlines }\end{array}$ \\
\hline L10. & $\begin{array}{l}\text { Courses are designed to support diverse learning styles } \\
\text { and learner capabilities }\end{array}$ \\
\hline \multicolumn{2}{|c|}{$\begin{array}{l}\text { Development : Processes surrounding the creation and } \\
\text { maintenance of e-learning resources }\end{array}$} \\
\hline D1. & $\begin{array}{l}\text { Teaching staff are provided with design and development } \\
\text { support when engaging in e-learning }\end{array}$ \\
\hline D2. & $\begin{array}{l}\text { Course development, design and delivery are guided by e- } \\
\text { learning procedures and standards }\end{array}$ \\
\hline D3. & $\begin{array}{l}\text { An explicit plan links e-learning technology, pedagogy } \\
\text { and content used in courses }\end{array}$ \\
\hline D4. & Courses are designed to support disabled students \\
\hline D5. & $\begin{array}{l}\text { All elements of the physical e-learning infrastructure are } \\
\text { reliable, robust and sufficient }\end{array}$ \\
\hline D6. & $\begin{array}{l}\text { All elements of the physical e-learning infrastructure are } \\
\text { integrated using defined standards }\end{array}$ \\
\hline D7. & $\begin{array}{l}\text { E-learning resources are designed and managed to } \\
\text { maximise reuse }\end{array}$ \\
\hline \multicolumn{2}{|c|}{$\begin{array}{l}\text { Support : Processes surrounding the support and operational } \\
\text { management of e-learning }\end{array}$} \\
\hline S1. & $\begin{array}{l}\text { Students are provided with technical assistance when } \\
\text { engaging in e-learning }\end{array}$ \\
\hline S2. & $\begin{array}{l}\text { Students are provided with library facilities when } \\
\text { engaging in e-learning }\end{array}$ \\
\hline S3. & $\begin{array}{l}\text { Student enquiries, questions and complaints are collected } \\
\text { and managed formally }\end{array}$ \\
\hline S4. & $\begin{array}{l}\text { Students are provided with personal and learning support } \\
\text { services when engaging in e-learning }\end{array}$ \\
\hline S5. & $\begin{array}{l}\text { Teaching staff are provided with e-learning pedagogical } \\
\text { support and professional development }\end{array}$ \\
\hline S6. & $\begin{array}{l}\text { Teaching staff are provided with technical support in } \\
\text { using digital information created by students }\end{array}$ \\
\hline \multicolumn{2}{|c|}{$\begin{array}{l}\text { Evaluation : Processes surrounding the evaluation and quality } \\
\text { control of e-learning through its entire lifecycle. }\end{array}$} \\
\hline E1. & $\begin{array}{l}\text { Students are able to provide regular feedback on the } \\
\text { quality and effectiveness of their e }\end{array}$ \\
\hline $\mathrm{E} 2$. & $\begin{array}{l}\text { Teaching staff are able to provide regular feedback on } \\
\text { quality and effectiveness of their e }\end{array}$ \\
\hline E3. & Regular reviews of the $\mathrm{e}$ \\
\hline \multicolumn{2}{|c|}{$\begin{array}{l}\text { Organisation: Processes associated with institutional planning and } \\
\text { management }\end{array}$} \\
\hline O1. & $\begin{array}{l}\text { Formal criteria guide the allocation of resources for e- } \\
\text { learning design, development and delivery }\end{array}$ \\
\hline $\mathrm{O} 2$. & $\begin{array}{l}\text { Institutional learning and teaching policy and strategy } \\
\text { explicitly address e-learning }\end{array}$ \\
\hline O3. & $\begin{array}{l}\text { E-learning technology decisions are guided by an explicit } \\
\text { plan }\end{array}$ \\
\hline $\mathrm{O} 4$. & $\begin{array}{l}\text { Digital information use is guided by an institutional } \\
\text { information integrity plan }\end{array}$ \\
\hline $\mathrm{O} 5$. & $\begin{array}{l}\text { E-learning initiatives are guided by explicit development } \\
\text { plans }\end{array}$ \\
\hline O6. & Students are provided with information on e-learning \\
\hline
\end{tabular}


International Conference on Rural Information and Communication Technology 2011

\begin{tabular}{|l|l|}
\hline & technologies prior to starting courses \\
\hline O7. & $\begin{array}{l}\text { Students are provided with information on e-learning } \\
\text { pedagogies prior to starting courses }\end{array}$ \\
\hline O8. & $\begin{array}{l}\text { Students are provided with administration information } \\
\text { prior to starting courses }\end{array}$ \\
\hline O9. & $\begin{array}{l}\text { E-learning initiatives are guided by institutional strategies } \\
\text { and operational plans }\end{array}$ \\
\hline
\end{tabular}

\subsection{Dimension of Capability}

Capability at the higher dimensions that is not supported by capability at the lower dimensions will not deliver the desired outcomes; capability at the lower dimensions that is not supported by capability in the higher dimensions will be ad-hoc, unsustainable and unresponsive to changing organizational and learner needs.

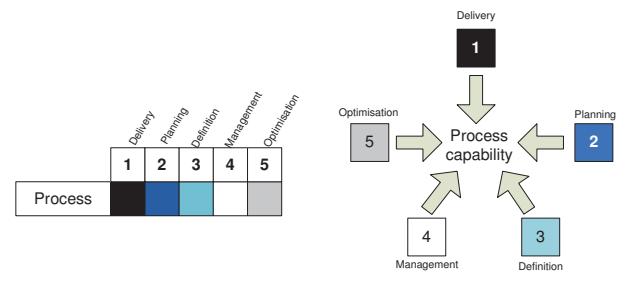

Figure 4. eMM process dimension [7].

Dimension 1 (Delivery) is concerned with the creation and delivery of process outcomes. Dimension 2 (Planning) assesses the use of predefined objectives and plans in conducting the work of the process. Dimension 3 (Definition) covers the use of institutionally defined and documented standards, guidelines, templates and policies during the process implementation. Dimension 4 (Management) is concerned with how the institution manages the process implementation and ensures the quality of the outcomes. Dimension 5 (Optimisation) captures the extent an institution is using formal approaches to improve capability measured within the other dimensions of this process.

\subsection{Practices}

Each process is further broken down within each dimension into practices that are either essential (listed in bold type) or just useful (listed in plain type) in achieving the outcomes of the particular process from the perspective of that dimension. The use of these detailed lists of practices provides a way of making explicit the essential aspects of the eMM processes which can then be used to develop action plans and strategies addressing aspects of particular weakness or opportunity for a sector or institution.

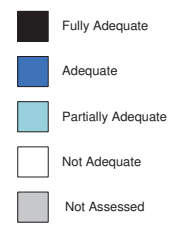

Figure 5. eMM capability assessments [10].

The ratings at each dimension are done on the basis of the evidence collected from the institution and are a combination of whether or not the practice is performed, how well it appears to be functioning, and how prevalent it appears to be.
A rating of Not Adequate indicates that there is currently no evidence of the practice occurring in the institutional context, nor usually a recognition of the practice outcomes in normal institutional activities. A rating of Partially Adequate indicates that major shortcomings or limitations in practice outcomes are evident. A rating of Largely Adequate indicates that the practice outcomes are being achieved but that more formalisation is needed to ensure sustainability, or that a more systematic consideration of activities has been lacking. A rating of Fully Adequate indicates that the process outcomes are currently being clearly and sustainably addressed and achieved.

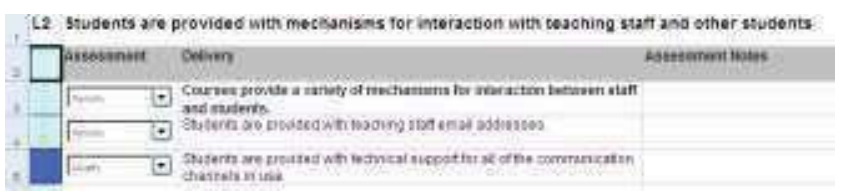

Figure 6. eMM capability assessments practices [10].

\section{IMPLEMENTATION EXAMPLE OF eMM ASSESSMENT}

After the assessment of capability is undertaken, the results can be interpreted. Table II describe some typical results showing a single process capability as assessed for three different sample University [10].

Table 2. Example practice result comparing three university

\begin{tabular}{|c|c|c|c|c|c|}
\hline \multicolumn{6}{|c|}{ Process Description } \\
\hline & 1 & 2 & 3 & 4 & 5 \\
\hline University X & & & & & \\
\hline University Y & & & & & \\
\hline University Z & & & & & \\
\hline
\end{tabular}

University X shows evidence of having defined standards or guidelines for performing the process (adequate rating at level 3). However, these do not appear to be having an impact on actual elearning projects as shown by the lower ratings at level 1 (partially adequate) and level 2 (partially adequate).

University Y shows a pattern of very good performance of the process (fully adequate rating at level 1), supported by largely adequate planning (level 2) and an initial set of standards or guidelines (partially adequate rating at level 3 ). This is perhaps the expected pattern of capability development, building from a base of ad-hoc behaviours that are becoming more standardised as the institution has more experience in e-learning.

Finally, University $\mathrm{Z}$ performs the process very well (fully adequate rating at level 1) supported by effective planning (fully adequate rating at level 2), largely adequate standards and guidelines (level 3) and an initial programme of evaluation and measurement of process performance (partially adequate at level $4)$.

\section{CONCLUSION}

eMM is one methodology that can be used a higher education in developing e-learning and to ensure that e-learning design, development and delivery according with the needs of students, staff, and institutions. eMM goal is to help the institutions created 
International Conference on Rural Information and Communication Technology 2011

to assess and compare the potential ability to develop, deploy, and support existing e-learning. This assessment result will provide comprehensive information that can be used as a guide to design strategic and operational planning and investment, or design a roadmap to higher education institutions in improving the process of e-learning.

\section{REFERENCES}

[1] Dublin, L. 2003. If you only look under the street lamps..... Or nine e-Learning Myths. The e-Learning Developers Journal. Retrieved July 2005 from http://www. eLearningguild.com.

[2] Stockley, D. 2005. Definition of e-Learning. Retrieved July 222005 from http://derekstockley.com.au/elearningdefinition.html

[3] Singh, G., O’ Donoghue, J. \& Worton, H. 2003. A study into the effects of e- Learning on higher education. JUTLP, (2) 1. Retrieved July 22, 2005 from http://jutlp.uow.edu.au/ 2005 v02_i01/odonoghue003.html

[4] Zemsky, R., \& Massy, W.F. 2004. Thwarted Innovation, What happened to e-learning and why, A final report for the Weather station Project of the Learning Alliance at the
University of Pennsylvania in cooperation with the Thomson Corporation, Pennsylvania.

[5] Nichols, M. 2008. E-learning in context. Laidlaw College, Auckland, New Zealand. (E-Primer Series.) http:// akoaotearoa.ac.nz/sites/default/ files/ng/group-661/n877-1elearning-in-context.pdf. (Accessed 8 March, 2010)

[6] Resta, P. and Patru, M. (Eds). 2010. Teacher Development in an E-learning Age: A policy and Planning Guide. Paris, UNESCO.

[7] Marshall, S., eMM Version 2.3 Process Description, Victoria University of Wellington, Wellington, 2007.

[8] Marshall, S. and Mitchell, G. 2003. Potential Indicators of e-Learning Process Capability. Proceedings of EDUCAUSE in Australasia 2003, Adelaide, Australia.

[9] M. Paulk, C. Weber, S. Garcia, M. B. Chrissis, and M. Bush. 1993. Key Practices of the Capability Maturity Model, Technical Report CMU/SEI-93-TR-025, Software Engineering Institute.

[10] Marshall, S., eMM Core Version 2.3 Self-Assessment Workbook, Victoria University of Wellington, Wellington, 2007. 